\title{
Life Skill Training and Entrepreneurship Mentoring: Effort to Maintain Functional Literacy
}

\author{
Masykur $^{1}$, Asep Supriyatna ${ }^{2}$, Ana Maulana ${ }^{3}$, Arik Darojat ${ }^{4}$ \\ \{maskur@institutpendidikan.ac.id ${ }^{1}$, asupriyatna59@gmail.com² ${ }^{2}$, \\ anamaulana@institutpendidikan.ac.id ${ }^{3}$, arikdarojat@institutpendidikan.ac.id $\left.{ }^{4}\right\}$ \\ 1),2),3),4) Institut Pendidikan Indonesia, Jl. Terusan Pahlawan No.83, Garut 44151
}

\begin{abstract}
The illiteracy returned by some of the leaners who have taken basic level literacy education is proved. This happens because it is not maintained and not used in everyday life. On the other hand, adult literacy is an important component of the education aspect which can increase the human development index. This study was designed using Research and Development method with data analysis techniques conducted by comparing the conditions before and after using the model of life skills training and entrepreneurship accompanied (before-after) to one group (one group pretest-posttest design) with one type of treatment. The results of the study show that the new model has proved effective to maintain the literacy skills of leaner at basic level functional literacy education.
\end{abstract}

Keywords: Life skills training, entrepreneurship accompanied, and literacy.

\section{Introduction}

Literacy is the ability to read, write, and count and have functional abilities needed in everyday life. For this purpose a variety of literacy education programs have been carried out including one of them is basic level functional literacy education that has been followed by the community as citizens of learning Riung Gunung Community Learning Center (PKBM) in Bungbulang District, Garut Regency, West Java Province. However, the phenomenon of the emergence of illiteracy back from some of the learning citizens who have been taught is proven. Most of the residents learned functional literacy from 15 participants; 10 participants experienced illiteracy again because they were not maintained and not used in daily life. This phenomenon is also by the writings of Suryadi (2009: 102) which states that: "... illiteracy again after participating in literacy education programs is estimated to reach $30 \% "$ ". Sihombing (1999: 52) states that "... community education does not need to have a standard progra; various models must be developed". And the development of the new model is associated with economic or entrepreneurial activities in harmony with the writings of Kusnadi et al. (2005: 10) which states: "... reasoning that economic motivation plays a major role in relation to functional literacy". On the basis of the problems of several expert writings, a model for life skills training and entrepreneurship assistance was developed to try to maintain the literacy skills of the learning community so that they would not be illiterate again. 


\section{Research Methodology}

This study was designed using the "Research and Development," Research and Development "approach". According to Borg and Gall (1996: 782), the research and development model is "A process used to develop and validate educational products". Respondents and Research Locations were troubled citizens of basic literacy education learning who had attended previous literacy education, namely ten people (purposive sampling) who lived in Bungbulang District, Garut Regency, West Java Province. Data collection techniques and tools used in this study were observations structured nonparticipants, closed structured interviews, documentation studies in the form of studying the report on the implementation of the old training model, and conducting an evaluation process in the form of a test of action on the new conceptual model. The data analysis technique has done by comparing the conditions before and after using the life skills training model and entrepreneurship assistance to one group (one group pretest-posttest design) with one type of treatment.

\section{Result and Discussion}

For the results of the study, it can be seen from the table below which is the result of data processing for the development of new models constructed by researchers as follows.

Table 1. Participants in the Development of the Skills Training and Entrepreneurship Assistance Model for Efforts to Maintain the Literacy Ability of the Study Residents in Bungbulang District, Garut Regency, West Java Province

t-Test: Paired Two Sample for Means

\begin{tabular}{lrr}
\hline & X1 (Old model) & X2 (New model) \\
\hline Mean & 36 & 86.5 \\
Variance & 37.77777778 & 22.5 \\
Observations & 10 & 10 \\
Pearson Correlation & 0.609772747 & \\
Hypothesized Mean Difference & 0 & \\
df & 9 & \\
t Stat (t hitung) & -32.11793576 & \\
P(T<=t) one-tail & $6.75582 \mathrm{E}-11$ & \\
$\mathrm{t}$ Critical one-tail & 1.833112933 & \\
$\mathrm{P}(\mathrm{T}<=\mathrm{t})$ two-tail & $1.35116 \mathrm{E}-10$ & \\
$\mathrm{t}$ Critical two-tail & 2.262157163 & \\
\hline
\end{tabular}


Source: Results of data processing and conversion of Microsoft excel to word statistical analysis.

Furthermore, it can be explained that: The level of significance is $5 \%(\alpha=0.05)$, while the degree of freedom (df) is $\mathrm{n}-1=9$. For Excel programs the probability value must be multiplied by 2 , so that for 0.05 the program become $t$ table $=\operatorname{TINV}(0.05,9)=2.262157163$ or 2,2622. In this case, one side calculation is used because of the use of " $<$ " in the formulation of the hypothesis. Also the sign " $<$ " means that the test is carried out on the left side of the normal distribution, which means the number $t$ table above becomes - 2,2622.

Calculate from the results of the computer output above, in the description line "t Stat" the results of $t$ count are - 32,1179

Rules and decision making

By comparing $t$ table and $t$ count:

If $\mathrm{t}$ count $\geq \mathrm{t}$ table, then $\mathrm{H} 0$ is accepted.

If $\mathrm{t}$ count $<\mathrm{t}$ table, then $\mathrm{H} 0$ is rejected.

From the rules of the decision above, then:

Because $t$ count $(-32,1179)<t$ table $(-2,2622)$, then Ho is rejected, meaning that there is actually a significant (significant) difference between the average before and after using a new model in an effort to maintain literacy ability, which means that the development of a model of life skills training and entrepreneurship assistance to efforts to maintain the literacy skills of the learning community carried out has been effective in other words that the development of a new model for treatment in an experiment in an effort to maintain literacy skills is more effective than the previous model. This can be described as follows.

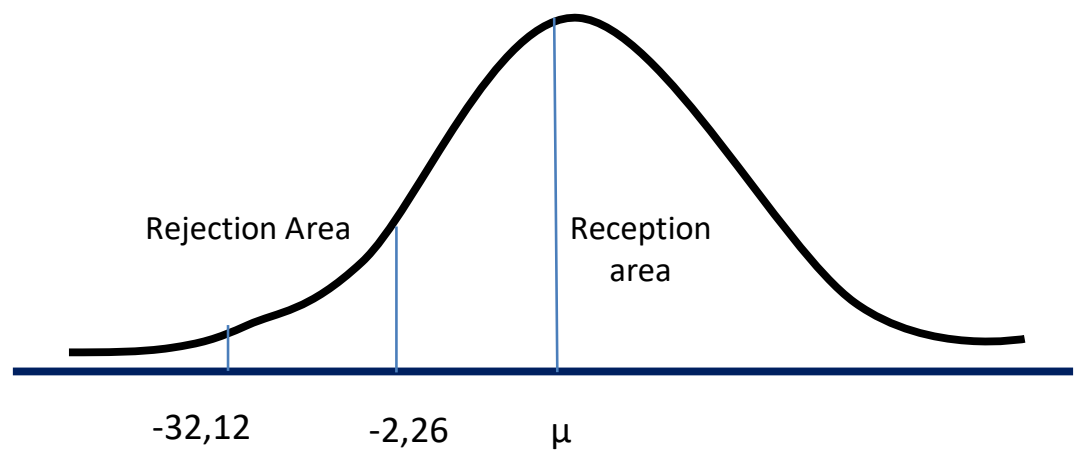

Figure 1. Rejection area and reception area

The ability to return to the literacy of the learning people who have been treated through experiments is significantly more effective than the old model. This means that the development of new models has proven to be significantly influential in the effort to maintain the literacy skills of the learning community so that they are not illiterate again. This is in line with Kusanagi's writing which states that through an economic approach it is hoped that it can motivate more learning citizens to maintain 
literacy (Kusnadi et al., 2005: 10). Likewise, the development of a new model as one of the innovations seems to be in line with the writings of Sihombing (1999: 52) which states that "... public education does not need to have a standard program; various models must be developed". One of the models constructed by researchers is the model of life skills training and entrepreneurship assistance. Thus the model name is: "Life Skills Training Model and Entrepreneurship Assistance to Efforts to Maintain Literacy Capabilities of Study Residents in Bungbulang District, Garut Regency, West Java Province".

Significance testing of the effectiveness of the development of the new model was carried out through an experimental model (before-after) which used ten random learning citizens. Then the 10 study residents were given an action test before and after taking a new model of life skills training. For data analysis techniques the development of a model of life skills based on local potential (before-after) on one group (one group pretest-posttest design) and prove the significance of differences before and after experiments through the development of new models need to be statistically tested with correlated t-test (related). The significance level is $5 \%(\alpha=$ $0.05)$, while the degree of freedom (df) is $\mathrm{n}-1=9$. For the Excel program, the probability value must be multiplied by two so that for 0.05 the program become $t$ table $=\operatorname{TINV}(0.05,9)=2.262157163$ or 2,2622 . In this case, one side calculation is used because of the use of " $<$ "in the formulation of the hypothesis. Also the sign " $<"$ means that the test is carried out on the left side of the normal distribution, which means the number $t$ table above becomes - 2,2622. From the results of the computer output above, in the description line "t Stat" the results of $t$ count are - 32,1179. Because t count $(-32,1179)<\mathrm{t}$ table $(-2,2622)$, then Ho is rejected, meaning that there is actually a significant (significant) difference between the average before and after the development of the new model which means that the development of new models is done it has been effective in other words that the development of a new model as a treatment in an experiment in an effort to maintain the literacy skills of the learning population proved to be more effective than the previous model.

\section{Conclusion}

That there is a significant (significant) difference between the average before and after the development of the new model, which means that the new model carried out is more effective in other words that the new model as a treatment is more effective than the previous model.

\section{Reference}

Abdulhak, I. (1990). Program Kerja Paket A Hubungannya dengan motivasi Meningkatkan Pendapatan dan Motivasi Mengikuti Pendidikan Lanjutan. Disertasi Sekolah Pascasarjana IKIP Jakartaa: Tidak diterbitkan. Anwar. (2008). Pendidikan Kecakapan Hidup. Bandung: Alfabeta.

Arikunto, S. (2002). Dasar-dasar Evalkuasi Pendidikan. Jakarta: Bumi Aksara.

Borg dan Gall. (1996). Educational Research: An Introduction (Third Ed). New 
York: Longman.

Buku Modul Keaksaraan Berbasis Masyarakat Desa. 2008. Direktorat Pendidikan Masyarakat. Direktorat Jendral Pendidikan Nonformal dan Informal. Departemen Pendidikan nasional. Jakarta.

Djakman, D, C dan Silvira, V. (1994). Sain Manajemen. Buku Dua. Edisi Ke Empat. Jakarta: Salemba.

Geoffrey. G. M. (1996). Kewirausahaan: Teori dan Praktik. Jakarta: Pustaka Presindo.

Hatimah, I. (2005). Pengembangan Model Pengelolaan Pembelajaran Berbasis Potensi Lokal. Disertasi Doktor pada Sekolah Pascasarjana UPI Bandung: Tidak diterbitkan.

Hatimah, I, dkk (2007). Pembelajaran Berwawasan Kemasyarakatan (Edisi Satu). Jakarta: Universitas Terbuka.

Irianto, A. (2007). Statistik: Konsep Dasar dan Aplikasinya. Jakarta: Kencana.

Kamil, M. (2010). Model Pendidikan dan Pelatihan: Konsep dan Aplikasi. Bandung: CV Alfabeta.

Kusmiadi, A. (2009). "Model Pembelajaran Pasca Keaksaraan Melalui Penguatan Pendidikan Kecakapan Hidup Bagi Upaya Pemberdayaan Perempuan Pedesaan”. Jurnal PNFI.1, (1),11.

Kusnadi, dkk. (2005). Pendidikan Keaksaraan: Filosofi, Strategi, Implementasi. Jakarta: Departemen Penidikan Nasional Dirjen PLS, Direktorat Dikmas.

McMillan. J.H. dan Schumacher.S. (2001). Research and Education: A

Conceptual Introduction (Fifth Ed). New York: Longman.

Millan, Mc. J, Dan Schumacher, S. (1999). Research In Education. New York: Longman.

Sihombing, U. (2001). Pendidikan Luar Sekolah: Masalah, Tantangan dan Peluang. Jakarta: CV Wirakarsa.

Sihombing, U. (2000). Pendidikan Luar Sekolah: Manajemen Strategi. Jakarta: PD Mahkota.

Srinivasan, L. (1977). Beberapa Pandangan Mengenai Pendidikan Nonformal Bagi Orang Dewasa (Terjemahan). Bandung: BPKB Jayagiri.

Sudjana. (2004). Pendidikan Nonformal: Wawasan, Sejarah Perkembangan, Filsafat, Teori Pendukung, Asas. Cetakan Pertama. Bandung; Falah Production.

Sugiyono. (2007). Metode Penelitian Administrasi. Bandung: Alfabeta.

Sugiyono. (2007). Metode Penelitian Administrasi: Dilengkapi dengan Metode

$R \& D$. Bandung: ALFABETA.

Sugiyono. (2009). Metode Penelitian Kuantitatif, Kualitatif dan $R$ \& D. Bandung: Alfabeta.

Suryadi, A. (2009). Mewujudkan Masyarakat Pembelajar: Konsep, Kebijakan dan Implementasi. Bandung: Widya Aksara Press.

Suryana (2003). Kewirausahaan: Pedoman Praktis, Kiat dan Proses Menuju Sukses. Jakarta: PT Salemba Empat.

Wahyudin. (2000). Modul Pelatihan Untuk Pelatih. BAPPENAS : Jakarta. 